\title{
An Unusual Case of Eclampsia at 21 Weeks of Gestation with Multiple Risk Factors Except Molar Pregnancy
}

\author{
Yirmi Birinci Gebelik Haftasında Gelişen Molar Gebelik Dışında Birçok Risk Faktörüne Sahip Nadir Bir Eklampsi \\ Olgusu
}

\section{Tuğba Kınay ${ }^{1}$, Erdem Fadıloğlu ${ }^{1}$, Funda Akpınar ${ }^{1}$, Serdar Yalvaç², Ömer L. Tapısız ${ }^{1}$}

${ }^{1}$ University of Health Sciences Ankara Etlik Zubeyde Hanim Health Practice Research Center, Ankara, Turkey

${ }^{2}$ Bozok University, Faculty of Medicine, Yozgat, Turkey

\begin{abstract}
Preeclampsia/eclampsia is a serious complication of the pregnancy and earlyonset disease is mostly associated with molar pregnancy. We present a rare case of eclampsia that occurred at very early weeks of gestation and had multiple risk factors for preeclampsia, but not molar pregnancy. A 35-year-old woman (gravidity 11, parity 1) presented with eclampsia at 21 weeks of gestation. She had history of preeclampsia in previous pregnancy, chronic hypertension, recurrent pregnancy loss (a total of 9 abortions at 6-21 weeks of gestation) and methyltetrahydrofolatereductase (MTHFR) heterozygous mutation. The pregnancy was terminated by hysterotomy. Molar change was not observed in the placenta. No postoperative complication occurred and the patient was discharged with antihypertensive therapy. Eclampsia is a severe form of the preeclampsia and clinicians should keep in mind that it may be occurred at very early weeks of gestation in patients with multiple risk factors for preeclampsia.
\end{abstract}

Key Words: Eclampsia, gestational age, risk factors

Received: 10.19 .2017

Accepted: 01.03.2018

\section{ÖZET}

Preeklampsi/eklampsi gebeliğin ciddi bir komplikasyonudur ve erken başlangıçlı hastalık çoğunlukla molar gebelik ile ilişkilidir. Biz gebeliğin çok erken haftalarında gelişen, çok sayıda risk faktörüne sahip ancak molar gebeliği bulunmayan nadir bir eklampsi olgusunu sunduk. Otuz beş yaşındaki hasta (gravida 11, parite 1) 21. gebelik haftasında eklampsi geçirdi. Hastanın önceki gebeliğinde preeklampsi, kronik hipertansiyon, tekrarlayan gebelik kaybı (6-21. gebelik haftaları arasında toplam 9 abort) ve metiltetrahidrofolatredüktaz (MTHFR) heterozigot mutasyon öyküsü mevcuttu. Gebelik histerotomi ile sonlandırıldı. Plasentada molar değişiklik izlenmedi. Postoperatif komplikasyon olmadı ve hasta antihipertansif tedavi ile taburcu edildi. Eklampsi preeklampsinin şiddetli bir formudur ve klinisyenler preeklampsi için çok sayıda risk faktörüne sahip hastalarda çok erken gebelik haftalarında hastalığın gelişebileceğini akılda tutmalıdırlar.

Anahtar Sözcükler: Eklampsi, gestasyonel yaş, risk faktörleri

Geliş Tarihi: 19.10.2017

Kabul Tarihi: 03.01.2018

\section{INTRODUCTION}

Preeclampsia is a leading cause of the maternal and perinatal morbidity and mortality (1). Etiology of preeclampsia is not known exactly. However, many risk factors associated with preeclampsia such as older maternal age, nulliparity, obesity, multifetal gestation, previous preeclampsia, chronic hypertension, diabetes mellitus, molar pregnancy, chronic autoimmune disease, and renal disease have clarified (1). Eclampsia is the severe form of preeclampsia and characterized by convulsions in patients with preeclampsia findings. It usually occurs last trimester of pregnancy and may emerge at antepartum, intrapartum and postpartum period (2). Unlike the literature, we presented an unusual eclampsia case with multiple risk factors occurred at 21 weeks of gestation, much earlier than expected weeks.

\section{CASE REPORT}

Thirty five-year-old woman (gravidity 11 , abortion 9, and parity 1) referred to the emergency service at 21 weeks of gestation with the complaints of unconsciousness and generalized tonic-clonic seizure two times. She had history of recurrent pregnancy loss (a total of 9 abortions at 6, 6, 12, $16,16,19,19,21$ and 21 weeks of gestation), and chronic hypertension. Despite the use of antihypertensive drugs, unregulated chronic hypertension was present in her all pregnancies. She had also history of preterm delivery with cesarean section due to severe preeclampsia at 26 weeks of gestation. Screening for thrombophilia was carried out before the current pregnancy and methyltetrahydrofolate reductase (MTHFR) heterozygous mutation was detected. 
According to her medical records, she had no renal disease, diabetes mellitus, antiphospholipid antibody syndrome and other chronic autoimmune diseases. She was using metildopa, low molecular weight heparin and asprin since the first trimester of the current pregnancy. Her blood pressure was 170/100 $\mathrm{mmHg}$ at admission, fetal biometry was consisted with 21 weeks of gestation. In physical examination confusion, pretibial edema, and periorbital ecchymosis due to trauma during seizure were observed. In laboratory findings, hemoglobin level was $14 \mathrm{gr} / \mathrm{dl}$, platelet count was $368,000 \mathrm{cell} / \mathrm{mm}^{3}$, alanine aminotransferase (ALT) level was $21 \mathrm{IU} / \mathrm{L}$, aspartate aminotransferase (AST) level was $26 \mathrm{IU} / \mathrm{L}$, creatinine level was $0.9 \mathrm{mg} / \mathrm{dl}$ and there was $3+$ proteinuria. Intravenous hydralazine and $2 \mathrm{gr} / \mathrm{h}$ magnesium sulphate were administered for blood pressure regulation and seizure control. The pregnancy was terminated by hysterotomy due to the eclampsia indication. Fetal weight was $300 \mathrm{gr}$ and no major congenital anomaly was observed. There was not hydatiform change or another pathological finding in the placenta. No complication occurred and the patient recovered consciousness and blood pressure was discharged with oral amlodipine treatment.

\section{DISCUSSION}

Preeclampsia/eclampsia at early gestational weeks is rare and serious complication of pregnancy and mostly associated with molar pregnancy (3). A literature research revealed few published case reports of eclampsia without molar pregnancy at $<22$ weeks of gestation (4-6). In these reports, 1 case had older age (4) and 2 had primigravidity alone $(5,6)$ as a risk factor. In 1985 , a 43 year old eclampsia case at 18 weeks of gestation was reported (4). In another report, a first pregnancy complicated with eclampsia at 21 weeks of gestation was terminated with prostaglandin E2 suppositories successfully (5). Gürel and Gürel (6) were also reported the eclampsia and HELLP syndrome occurred in an18 year old, primigravida woman at 19 weeks of gestation. Unlike the previous reports, our case had multiple risk factors together: history of chronic hypertension, previous preeclampsia, recurrent pregnancy loss, and MTHFR heterozygous mutation. In all case reports including ours, patients recovered well and no neurologic or any other sequel were recorded by authors.

Presented case had a history of delivery with cesarean section due to severe preeclampsia at 26 weeks of gestation. The recurrence risk in subsequent pregnancy was $32 \%$ in patients with history of severe preeclampsia at second trimester (7). In addition, superimposed preeclampsia occurs in $40 \%$ of women with chronic hypertension (2) and three or more early pregnancy loss increases the risk of preeclampsia (8). Recurrent pregnancy loss and preeclampsia share similar etiological factors and histopathological findings in spiral arterioles (9).
Hereditary thrombophilia is also a risk factor for preeclampsia. Livrinova et al (10) reported that the relative risk in patients with preeclampsia for MTHFR heterozygous mutation, and MTHFR homozygous were 1.7 and 2.73 .

As a conclusion; presented case had multiple risk factors for preeclampsia. Clinicians should keep in mind that the presence of many risk factors together may lead to occurrence of severe disease and eclampsia at the early weeks of gestation, and should inform patients about the adverse maternal and perinatal outcomes of severe preeclampsia.

\section{Conflict of interest}

No conflict of interest was declared by the authors.

\section{REFERENCES}

1. Pauli JM, Repke JT. Preeclampsia: Short-term and Long-term Implications. Obstet Gynecol Clin North Am. 2015;42:299-313

2. Cuero MR, Varelas PN. Neurologic Complications in Pregnancy. Crit Care Clin. 2016;32:43-59.

3. Sibai BM. Diagnosis, prevention, and management of eclampsia. Obstet Gynecol. 2005;105:402-10.

4. Ito M, Katabuchi $\mathrm{H}$, Yoshimura T, Matsui K, Nakayama M, Maeyama M. A Case of Eclampsia during the 18th Week of Gestation. Int J Gynaecol Obstet. 1985; 23: 395-8

5. Sampson MB, Thomason JL, Tomasi AM, Work BA Jr. Pregnancy termination in patients with pregnancy-induced hypertension or eclampsia at less than 22 weeks' gestation. Am J Obstet Gynecol. 1982;143:474-5.

6. Gürel SA, Gürel H. Early development of HELLP syndrome associated with eclampsia: a case report. European Journal of Obstetrics \& Gynecology and Reproductive Biology 1998; 76: 2413

7. Sibai BM, Mercer B, Sarinoglu C. Severe preeclampsia in the second trimester: recurrence risk and long-term prognosis. Am J Obstet Gynecol1991;165:1408-12.

8. Trogstad L, Magnus $P$, Moffett A, Stoltenberg C. The effect of recurrent miscarriage and infertility on the risk of pre-eclampsia. BJOG. 2009;116:108-13

9. Roberts JM. Pathophysiology of ischemic placental disease. Semin Perinatol. 2014;38:139-45.

10. Livrinova $\mathrm{V}$, Lega $\mathrm{MH}$, Dimcheva $\mathrm{AH}$, Samardziski I, Isjanovska R. Factor $\mathrm{V}$ Leiden, Prothrombin and MTHFR Mutation in Patients with Preeclamsia, Intrauterine Growth Restriction and Placental Abruption. Open Access Maced J Med Sci. 2015;3:590-4. 